\title{
Identification of Organizational Culture maritime continent based that affects the growth and success of small and medium enterprises (SMEs) in South Sulawesi
}

\author{
Jumidah Maming ${ }^{1}$ \\ Amiruddin Amrullah ${ }^{2}$ \\ Andi Reni ${ }^{3}$ \\ ${ }^{1,2,3}$ Department of Management, Faculty of Economic, Hasanuddin University, Indonesia \\ *Corresponding Author's E-mail: jumidahmaming@yahoo.com
}

\begin{abstract}
Micro, Small and Medium Enterprises is one contributor to employment, growth in gross domestic product (GDP), and non-oil exports. And these types of businesses capable of facing exposure to storms of crisis and also has the ability to recover more quickly than larger business units.

As one part of Indonesian Maritime culture in the development of social welfare and environmental justice, then the identification of workplace culture that supports the growth and performance of SMEs needs to be done in order to determine its impact on growth and poverty reduction efforts.

This research using a descriptiveexplanatory method with Cultural Organizational Assessment Instrument $(\mathrm{OCAl})$. The population is the entire small business in the province of South Sulawesi. Criteria for small businesses based on the criteria according to Law Number 20 The year 2008 on Micro, Small, and Medium Enterprises. Sampling was conducted using a purposive sampling of small medium enterprises in the province of South Sulawesi with the criteria; has been in operation at least 10 years old and showed a significant asset growth compared to the beginning of the establishment. Analysis of the data will show the type of organizational culture at this time and 5 years later.
\end{abstract}

Keywords: organizational culture, growth, and success of small and medium enterprises (SMEs)

\section{INTRODUCTION}

Small and medium enterprises (SMEs) are one of the contributors towards employment, growth in gross domestic product (GDP), and the national oil and gas exports. This type of business and able to deal with exposure to Hurricane crisis and also has the ability to recover more quickly than with larger business units.

The conditions and the fact that in line with the results of empirical research conducted Demirbag et al., (2006) concluded that the success of the small and medium enterprises (small-medium enterprises) have a direct impact on the economic development both in developed countries or developing countries. The current SME presence is very important because of the main characteristics, the one because it is a labor-intensive business that absorbs labor (Tambunan, 2012). SME has the ability to create jobs with minimum cost, they are pioneers in the world of innovation and have the high flexibility that allows the business to meet the needs (ACS and Audretsch, 1990).

In Indonesia, it is the largest business sector SMES. The SME's contribution towards national development reached 2.607 Trillion 
GDP ratio Indonesia year 2008, while large companies only 2.087 trillion. Also in the absorption of manpower, SMEs reach about $97.04 \%$ while large companies only $2.96 \%$ (Primiana, 2011). In addition to SMES on its territory are also important players in the development of the local economy and community empowerment.

Data from the Ministry of Cooperatives and SMEs indicate that the number of units varies according to the small business sector of the economy, and most are concentrated in the sectors of agriculture, livestock, forestry, and fisheries, which in the year 2011 amounted to $26,685,710$ units and in 2012 experience increased became $26,967,963$ units or increased by $1.06 \%$. Likewise, the small businesses in the sectors of trade, hotels, and restaurants, the number of small businesses are experiencing an increase in the not-tooflashy from 15,910,964 units in the year 2011 be 15,918,251 units in the year 2012 or increased by $0.05 \%$, yet not so experienced by small businesses in the building sector, where the number of small businesses has increased very significantly from 570,640/outstanding unit in the year 2011 be 869,080 units in the year 2012 or increased by $52.30 \%$. Though quantitatively small businesses are the perpetrator of the Indonesia economy is the dominant activity, but in fact, it is the position of the sector was marginal. Small businesses face a situation of competition with the efforts of both medium and large in market inputs or outputs

Micro and small enterprise development is an integrated part of the development of small and medium enterprises (SMEs) in South Sulawesi. Development activities are intended as one of the pillars of the economic populist who can become the main driving force of the economy of the region, more specifically for the realization of the program "Gerbang Mas Taskin dan Agribisnis Komoditas Unggulan" in South Sulawesi.

Therefore, the attention of the Government of South Sulawesi province toward this sector is enormous. This is evidenced by the existence of strategies, programme and action plan (action plan) to develop micro and small (UMK). Some programs have been conducted for example training and mentoring, access to capital, and help market access for such business. However, the more facts on the ground indicate that not all programs are running effectively so that it can have an impact on the potential for performance degradation of small and micro enterprises (UMK) in South Sulawesi (Department of cooperatives and SMEs of South Sulawesi, 2012).

A variety of field research shows that small business industrial sector experienced a growth of only processing businesses that generate certain flagship products. Therefore efforts to identify investment opportunities in small business activities that produce flagship products that have the power to develop a need to be done. In addition to having a fairly high added value also absorb much manpower.

Although the Small Business provides a significant contribution to the Indonesian economy, but as a small business in the world hindered by various obstacles including the lack of innovation, lack of initiative and the ability for new technology, so that the cause of substantial that inhibits the growth performance of small businesses (Kuswantoro et al, 2012).

The fact that there is a 
demonstrated low performance of small businesses is caused by many factors. In fact, small businesses still lack competitiveness, less innovative, and market access. In addition, some results of the research States that the factors cause the failure of the sector of small and medium enterprises to flourish among these are: (1) the incompetence in management (management incompetence), (2) weak ability in decision making (poor decision making ability), (3) less experienced (lack of experience), (4) weak financial supervision (poor financial control) (Rus, 1999).

Until recently the study of growth and performance in SMES typically range in financial management, marketing, and operations, while associated with people in the Organization are still relatively few. Because SME has shown the important role in the economic development of a country and has a tough durability in the economic crisis of both national and global, it is important to learn about all of the greatness about SMES including the organizational culture. Although Ritchie (1993) States that employment relationship in the SME is characterized as informal, sometimes have a little formal control system, while sometimes there is no communications strategy. Small companies also facilitate an open communication and a family atmosphere that builds trust. In addition, other policies usually tend to be minimalist.

$$
\text { According to Martins \& }
$$

Terblanche (2003), the culture of the organization seems to be is a critical factor in the success of any organization. In large organizations, the main driver of development and success of the organization is the company culture. In the United States, almost all successful companies have different cultures; some of the most successful businesses in the last 10 years have been very dependent on the Organization's internal culture to create a competitive advantage (Cameron, 2004). With similar findings on SMES by Choueke and Armstrong (2000), stating that what is understood as "corporate culture" has a crucial role in the success of SMES.

Thus, to assist SMEs in South Sulawesi Province in order to develop rapidly and successfully, it is important to identify the type of cultural organization based on the Indonesian Maritime Continent affecting the growth and performance of SMEs.

The research objective, in general, is to identify the type of organizational culture that influences the growth and

performance of SMEs in South Sulawesi Province.

\section{MATERIALS AND METHODS Identification Variables}

The measurement variable is in theoretical and practical usefulness. The study of research and development on the concept of culture and culture of Indonesia related to the development of small and medium enterprises.

Being Practical Usefulness is; For the Government expected this research became the basis for making policy and taking decisions in developing small businesses which refers to the culture of the Organization and for the perpetrators of the small and medium enterprises (SMEs) can be used as information and inspiration in its business performance improvement efforts in order to become more developed and developing and achieving a competitive and sustainable competitiveness in the competition. 


\section{Research Analysis}

The study included a survey research category, where the data were collected through interviews based on the instrument/questionnaire. The questionnaire was structured in such a way so as to include information related to organizational culture that influences the growth and success of Enterprises, Small and Medium Enterprises (SMEs) using Cultural Organizational Assessment Instrument (OCAI) developed by Cameron and Quinn (2006). This framework is a quantitative survey method to assess the organizational culture.

A characteristic of Micro and Small Enterprises (MSEs) refers to Law no. 20 The year 2008 regarding Micro, Small and Medium Enterprises as follows:

1) Criteria for Micro Business as follows:

a. Have a net worth of at most Rp. $50,000,000.00$ (fifty million rupiah) excluding land and building of business premises; or

b. Have annual sales of at most $R p$. $300,000,000.00 \quad$ (three hundred million rupiah).

2) Criteria for Small Business as follows:

a. A stand-alone productive economic enterprise carried out by an individual or a business entity which is not a subsidiary or not a branch of a company owned, controlled, or becomes part directly or indirectly of a medium-sized or large-scale business

b. Have a net worth of more than Rp. $50,000,000.00$ (fifty million rupiah) up to a maximum of Rp. $500,000,000.00$ (five hundred million rupiah) excluding land and building of business premises; or

c. Has annual sales of more than Rp. $300,000,000.00$ (three hundred million rupiah) up to a maximum of Rp. 2.500.000.000,00 (two billion five hundred million rupiah).

3) Criteria of Medium Enterprises according to the Central Bureau of Statistics as follows:

a. Has a workforce between 20 people to 99 people

b. Productive business with a net worth more than Rp. 500,000,000.00 (two hundred million rupiah) up to a maximum of Rp. 10.000.000.000,00 (ten billion rupiah) excluding land and building of business place and can receive credit from bank equal to Rp. 500.000.000,00 (five hundred million rupiah) up to $\mathrm{Rp}$. $5,000,000,000.00$ (five billion rupiahs).

\section{Population and Sample}

That became the target population in this study are all small and medium enterprises who are at large district/city in South Sulawesi.

Sampling technique used was purposive sampling technique, namely the determination of the sample are tailored to the needs of the research. Sampling is done with the criteria; has been in operation for a minimum of 10 years and shows the development of a significant 
VILL SUB-

asset than the beginning of the establishment. The implementation of dissemination of the questionnaire in this study done by accidental sampling namely does research at a time when researchers met directly with the respondent.

\section{Types and sources of Data}

According to its kind, there are two types of data to be collected in this study, namely, primary data and secondary data. Primary data was collected through interviews and observations directly to the respondents. Secondary data can be obtained from two sources, namely external and internal sources
(Cooper and Emory, 2001; Sugiyono, 2005). The internal source is the data that comes from within the company respondents i.e. in the form of reports and notes the relevant activities with research variables. While the external data coming from outside companies such as published by the Office of the Department of industry and commerce, the Central Bureau of statistics and the Office of the Department of Cooperatives and SMEs in South Sulawesi. 


\section{NAME OF THE FORM OWNER}

\begin{tabular}{l|l|l} 
1. & Global & Dr. \\
Sejahter & Agnes \\
a & Sentosa \\
Bahagia & \\
\hline
\end{tabular}

2.

Ush. Ny.

Kerupuk Nurjana

Jahe

3.

4. PT.

Effem M.

Indones Ichsan

5.

ia Hasmin

Reso

Pamma Ibu Juni

6.

se

CV. Andi

Aman Mustafa

(Yayasa M, SPd

7. Harapa

$\mathrm{n}$

Bangsa) Eka

UD. S.Ag

Tunggal

Putri

Mandiri

8. Usaha

Alimuddi

CV.

UD.
AGES DISTRIC GENCY TS

\begin{tabular}{|l|l|} 
E & OF \\
NUMB & BUSINE \\
ER & SS \\
\hline
\end{tabular}

\section{Perorangan Komp.Bougen} ville Blok $\mathrm{C} / 2$

Perorangan Antang,

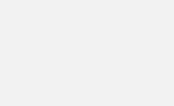

Kima 10

Kav A6

Makassar

Perorangan

Perum. Dosen

$\mathrm{UH}$

Tamalanrea

Jl. Kerukunan

Barat 15 Blok

J. No. 440

Makassar

JI. Barawaja I

No.

6

Makassar
Manggal

a

Makassa
$r$

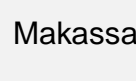

(0411)

49711

2

0411

Makassa

4666

$441 /$

0411 .

50832

48

(0411)

51570

Makassa

2

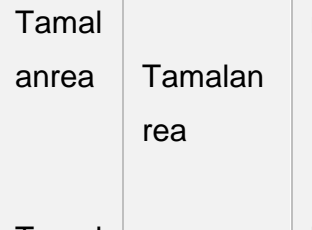

\begin{tabular}{l|l} 
Tamal & \\
anrea & Tamalan \\
& rea
\end{tabular}

Makassa

$r$

58315

3

$r$

(0411)

43942

9
Makassa

Makana

$\mathrm{n}$
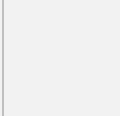

(

Makana

$\mathrm{n}$

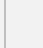

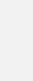


Susu

Sintari

9. Ush.

Minuma

$\mathrm{n}$

10.

12.

Ush. Kamarud

Madu din

11

KPK

Melati

CV.

Sinjai

Timur

13.

14.

Suka
Jaya

Jaya

Alna

Jaya n 


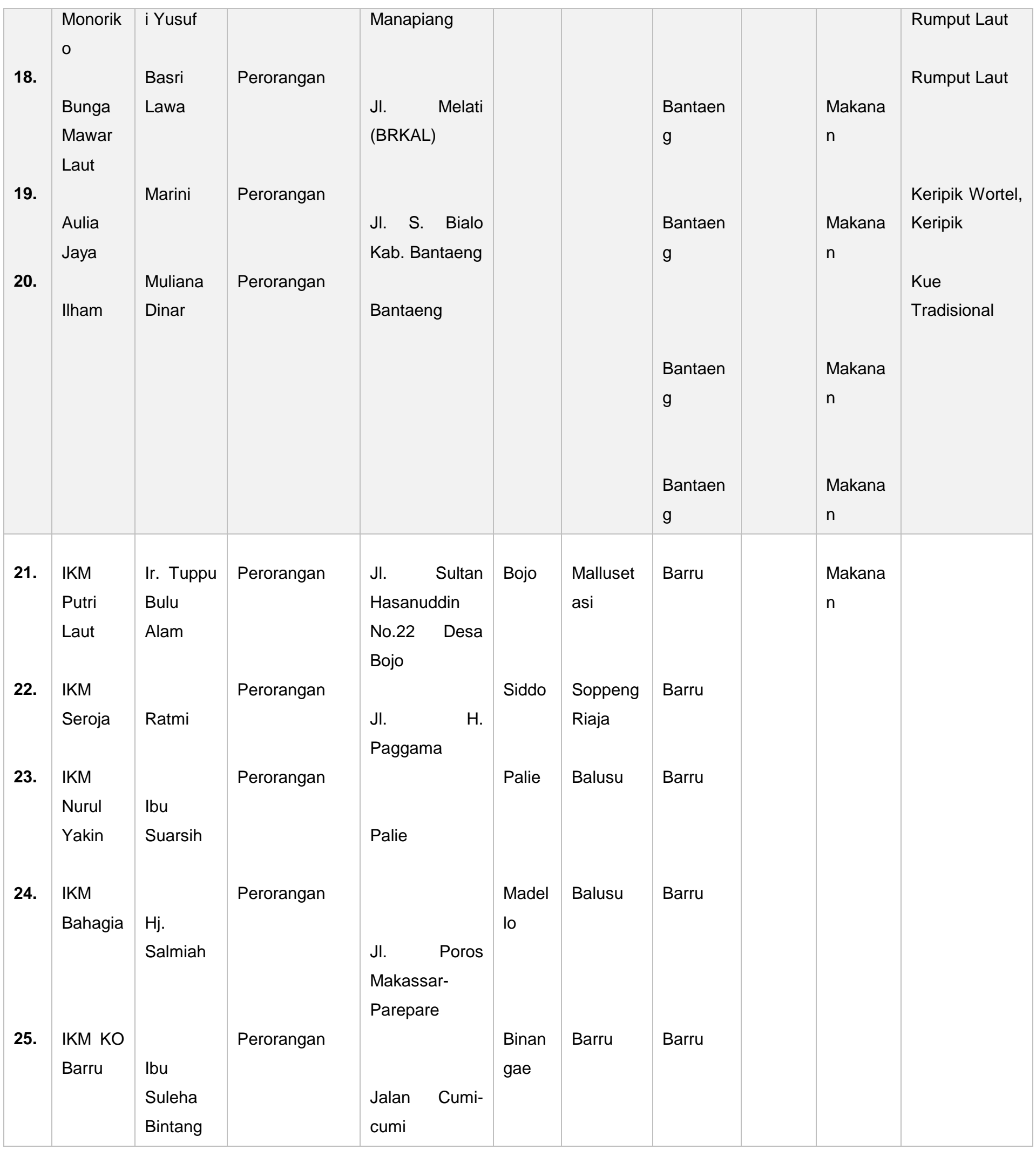




\begin{tabular}{|l|l|l|}
\hline Gender & $\begin{array}{l}\text { Frequency } \\
(\mathrm{F})\end{array}$ & $\begin{array}{l}\text { Percentage } \\
(\%)\end{array}$ \\
\hline Men & 90 & 90.0 \\
\hline Women & 10 & 10.0 \\
\hline Total & 100 & 100.0 \\
\hline
\end{tabular}

Profile of Micro Small and Medium Enterprises in South Sulawesi Province

Characteristics of Respondents

The respondent's characteristics are intended to give an idea of the identity of the respondent, which can be based on gender, age of respondent, type of education, respondent's profit, and duration of business, this is done to obtain a thorough and detailed description of the total number of each item in question Questionnaire, so it will be easier to interpret quantitatively.
Therefore, for more details will be presented a description of the identity of respondents by sex, the age of respondents, type of education and occupation of respondents that can be seen in the following table:

Profile of Respondents by Sex

Source: Primary data processed, 2016 
Profile of respondents by gender (gender) explains that from 100 people who participated in this study, it is dominated by male respondents that is as much as $90 \%$, followed by female respondents with the number of respondents as much as $10 \%$, so it can be concluded that the average entrepreneur SMEs are dominated by male respondents, this was due to the role of decision-making are on average been dominated by men.

Then it will be presented the profile of respondents by age can be presented through a table

Profile of Respondents by Age

\begin{tabular}{|l|l|l|}
\hline Age & $\begin{array}{l}\text { Frequency } \\
(\mathrm{F})\end{array}$ & $\begin{array}{l}\text { Percentage } \\
(\%)\end{array}$ \\
\hline $\begin{array}{l}<20 \\
\text { Years }\end{array}$ & 10 & 10.0 \\
\hline $\begin{array}{l}20-30 \\
\text { Years }\end{array}$ & 32 & 32.0 \\
\hline $\begin{array}{l}31-40 \\
\text { Years }\end{array}$ & 38 & 38.0 \\
\hline $\begin{array}{l}41-50 \\
\text { Years }\end{array}$ & 16 & 16.0 \\
\hline $\begin{array}{l}>50 \\
\text { Years }\end{array}$ & 4 & 4.0 \\
\hline Total & 100 & 100.0 \\
\hline
\end{tabular}

Source: Primary data processed, 2016

Based on data on respondent's profile by age, it is seen that the age of the respondents is $31-40$ years old with $38 \%$ of respondents, followed by respondents aged between $20-3032 \%$, followed by respondents aged between $41-50 \% 16 \%$, then followed by respondents aged $<20$ years i.e. as many as $10 \%$ and last by respondents aged> 50 years i.e. as much as $4 \%$. With the existing data, it can be concluded that most of SMEs aged between $31-40$ years of dominant leadership.

Next will be presented profiles of respondents based on the type of education respondents can be seen in the following table:

Profile of Respondents by Education

\begin{tabular}{|l|l|l|}
\hline $\begin{array}{l}\text { Educatio } \\
\mathrm{n}\end{array}$ & $\begin{array}{l}\text { Frequenc } \\
\mathrm{y}(\mathrm{F})\end{array}$ & $\begin{array}{l}\text { Percentag } \\
\mathrm{e}(\%)\end{array}$ \\
\hline $\mathrm{SD}$ & - & - \\
\hline SMP & 2 & 2.0 \\
\hline SMA & 34 & 34.0 \\
\hline Diploma & 22 & 22.0 \\
\hline S1 & 42 & 42.0 \\
\hline S2/S3 & - & - \\
\hline Total & 100 & 100.0 \\
\hline
\end{tabular}

Source: Primary data processed, 2016

Based on the table of respondents' profile by type of education, most respondents have S1 education level, $42 \%$ of respondents, followed by respondents who have education as high school students as much as $34 \%$, followed by respondents who have education as a diploma as much as $22 \%$ Followed by respondents who have education as junior high school students as much as $2 \%$, and $0 \%$ of respondents who have primary and secondary education. So it can be concluded that most respondents have a graduate education $\mathrm{S} 1$ as a leader of SMEs.

Then will be presented a profile of respondent based on profit (earnings) which can be presented in a table: 
Profile of Respondents According to Profit (Revenue)

\begin{tabular}{|l|l|l|}
\hline Income & $\begin{array}{l}\text { Frequenc } \\
\mathrm{y}(\mathrm{F})\end{array}$ & $\begin{array}{l}\text { Percentag } \\
\mathrm{e}(\%)\end{array}$ \\
\hline $\begin{array}{l}<500 \\
\text { thousan } \\
\mathrm{d}\end{array}$ & 19 & 19.0 \\
\hline $\begin{array}{l}\geq 500 \\
\text { thousan } \\
\mathrm{d}-1 \\
\text { million }\end{array}$ & 9 & 9.0 \\
\hline $\begin{array}{l}\geq 1- \\
\text { million }\end{array}$ & 22 & 22.0 \\
\hline $\begin{array}{l}\geq 2- \\
\text { million }\end{array}$ & 37 & 37.0 \\
\hline $\begin{array}{l}>5 \\
\text { million }\end{array}$ & 13 & 13.0 \\
\hline Total & 100 & 100.0 \\
\hline
\end{tabular}

Source: Primary data processed, 2016 Based on the table of respondents' profiles by income, it shows that the highest income of respondents in this study is with income $\geq$ Rp 2 million - Rp 5 million reaching $37 \%$ of respondents, followed by respondents who have income $\geq R p 1$ million - Rp 2 million Respondents as much as $22 \%$, followed by respondents who have income $<$ Rp500 thousand with the number of respondents as much as $19 \%$, followed by respondents who have income> Rp 5 million with the number of respondents as much as $13 \%$, and lastly by respondents who have income $\geq R p 500$ Thousand - Rp 1 million with the number of respondents as much as $9 \%$, so it can be concluded that Small and Medium Enterprises (SMEs) have income of $\geq R p 2$ million Rp 5 million.

Next will be presented profiles of respondents based on the length of business, respondents can be seen in the following table:

Profile of Respondents by Length of Running Business

\begin{tabular}{|l|l|l|}
\hline $\begin{array}{l}\text { Saving } \\
\text { Duration }\end{array}$ & $\begin{array}{l}\text { Frequency } \\
(\mathrm{F})\end{array}$ & $\begin{array}{l}\text { Percentage } \\
(\%)\end{array}$ \\
\hline $\begin{array}{l}<3 \\
\text { Months }\end{array}$ & 3 & 4.0 \\
\hline $\begin{array}{l}\geq 3-6 \\
\text { Months }\end{array}$ & 5 & 5.0 \\
\hline $\begin{array}{l}\geq 3-6 \\
\text { Months }\end{array}$ & 5 & 6.0 \\
\hline $\begin{array}{l}\geq 1-2 \\
\text { years }\end{array}$ & 31 & 22.0 \\
\hline$>2$ years & 56 & 63.0 \\
\hline Total & 100 & 100.0 \\
\hline
\end{tabular}

Source: Primary data processed, 2016 Based on the respondent's profile table according to the length of business, showed that SMEs as the most respondents in this study were $>2$ years to reach the number of respondents as much as $56 \%$, followed by the respondents with the long-running business $\geq 1$ - 2 years with the number of respondents $31 \%$, followed By the respondents with the duration of using 6 - 12 months and 3 - 6 months with the same number of respondents as much as $5 \%$, and the last by the respondents with the old use $<3$ months with the number of respondents as much as $3 \%$, so it can be concluded that most SMEs running their business $>2$ years.

\section{Description of Research Variables}

Description of the research is the result of research explaining about organizational culture affecting growth and success of Small and Medium Enterprises (SME) in South Sulawesi Province, based on the responses of 
respondents as the eligibility of respondents in providing information to the question of a questionnaire submitted. In the questionnaire, there are indicators of questions given answers consisting of 5 categories.

Range score:

Dominant Character Range Score

\begin{tabular}{|l|l|}
\hline $0-20$ & Very low \\
\hline $21-40$ & Low \\
\hline $41-60$ & Medium \\
\hline $61-80$ & High \\
\hline $81-100$ & Very high \\
\hline
\end{tabular}

Highest score: $20 \times 5=100$

Lowest score: $0 \times 1=0$

So the range for survey results $=(100-0) / 5=20$

Organization Leadership Score Range

\begin{tabular}{|l|l|}
\hline $0-20$ & Very low \\
\hline $21-40$ & Low \\
\hline $41-60$ & Medium \\
\hline $61-80$ & High \\
\hline $81-100$ & Very high \\
\hline
\end{tabular}

Highest score: $20 \times 5=100$

Lowest score: $0 \times 1=0$

So the range for survey results

$=(100-0) / 5=2$

Range Score of Personnel Management

Highest score: $20 \times 5=100$

Lowest score: $0 \times 1=0$

So the range for survey results $=(100-0)$

/ $5=20$

Range Score Adhesive Organization

\begin{tabular}{|l|l|}
\hline $0-20$ & Very low \\
\hline $21-40$ & Low \\
\hline $41-60$ & Medium \\
\hline $61-80$ & High \\
\hline $81-100$ & Very high \\
\hline
\end{tabular}

Highest score: $20 \times 5=100$

Lowest score: $0 \times 1=0$

So the range for survey results
$=(100-0) / 5=20$

Table 4.12

Range of Emphasized Strategy Score

\begin{tabular}{|l|l|}
\hline $0-20$ & Very low \\
\hline $21-40$ & Low \\
\hline
\end{tabular}

\begin{tabular}{|l|l|}
\hline $0-20$ & Very low \\
\hline $21-40$ & Low \\
\hline $41-60$ & Medium \\
\hline $61-80$ & High \\
\hline $81-100$ & Very high \\
\hline $41-60$ & Medium \\
\hline $61-80$ & High \\
\hline $81-100$ & Very high \\
\hline
\end{tabular}

Highest score: $20 \times 5=100$

Lowest score: $0 \times 1=0$

So the range for survey results

$=(100-0) / 5=20$

Range of Success Criteria Score

\begin{tabular}{|l|l|}
\hline $0-20$ & Very low \\
\hline $21-40$ & Low \\
\hline $41-60$ & Medium \\
\hline $61-80$ & High \\
\hline $81-100$ & Very high \\
\hline
\end{tabular}

Highest score: $20 \times 5=100$

Lowest score: $0 \times 1=0$

So the range for survey results

$=(100-0) / 5=20$

Respondents' Frequency and Response of Dominant Character, Organizational Leadership, Personnel Management, Organizational Adhesives, Emphasized Strategy, and Success Criteria Success on Growth and Small and Medium Enterprises (SMEs).

Frequency and description of respondents that describe the answers or responses of respondents regarding Organizational Leadership, Personnel Management,

Organizational Adhesives, Strategies are emphasized, and Success Criteria Success on Growth and Small and Medium Enterprises (SMEs), so in this study set 
of 100 respondents.

1. Dominant Character Variable

To know how far the respondent's response about the Dominant

Character toward growth and success of SMEs in South Sulawesi.
The answers of the respondents can be presented in Table 4:14.

Dominant Character Variable

\begin{tabular}{|c|c|c|c|c|c|c|c|c|c|c|c|}
\hline \multirow{2}{*}{ Question } & \multicolumn{2}{|c|}{$0-20$} & \multicolumn{2}{|c|}{$21-40$} & \multicolumn{2}{|c|}{$41-60$} & \multicolumn{2}{|c|}{$61-80$} & \multicolumn{2}{|c|}{$81-100$} & \multirow{2}{*}{ Score } \\
\hline & $\mathrm{F}$ & $\%$ & $\mathrm{~F}$ & $\%$ & $\mathrm{~F}$ & $\%$ & $\mathrm{~F}$ & $\%$ & $\mathrm{~F}$ & $\%$ & \\
\hline A & - & - & - & - & 31 & 31 & 52 & 52 & 17 & 17 & 386 \\
\hline$B$ & - & - & 1 & 1 & 21 & 21 & 57 & 57 & 21 & 21 & 398 \\
\hline C & - & - & 3 & 3 & 27 & 27 & 41 & 41 & 29 & 29 & 396 \\
\hline $\mathrm{D}$ & - & - & 1 & 1 & 21 & 21 & 57 & 57 & 21 & 21 & 398 \\
\hline Average & & & & & & & & & & & 394.5 \\
\hline
\end{tabular}

Source: Primary data processed, 2016

Based on the responses of respondents about the Dominant Character, the average answer most respondents pertained high in questions B and D amounted to 398 .

\section{Organizational Leadership Variables}

To know how far the respondent's response about Organizational Leadership to growth and success of Small and Medium Enterprises in South Sulawesi. The answers of the respondents can be presented in the following table:

Organizational Leadership Variables

\begin{tabular}{|c|c|c|c|c|c|c|c|c|c|c|c|}
\hline \multirow{3}{*}{ Question } & \multirow{2}{*}{\multicolumn{2}{|c|}{$0-20$}} & \multirow{2}{*}{\multicolumn{2}{|c|}{$21-40$}} & \multirow{2}{*}{\multicolumn{2}{|c|}{$41-60$}} & \multirow{2}{*}{\multicolumn{2}{|c|}{$61-80$}} & \multirow{2}{*}{\multicolumn{2}{|c|}{$81-100$}} & \multirow{3}{*}{ Score } \\
\hline & & & & & & & & & & & \\
\hline & $\mathrm{F}$ & $\%$ & $\mathrm{~F}$ & $\%$ & $\mathrm{~F}$ & $\%$ & $F$ & $\%$ & $F$ & $\%$ & \\
\hline $\mathrm{A}$ & - & - & - & - & 33 & 33 & 39 & 39 & 28 & 28 & 395 \\
\hline
\end{tabular}




\begin{tabular}{|l|l|l|l|l|l|l|l|l|l|l|l|} 
B & - & - & 1 & 1 & 21 & 21 & 58 & 58 & 20 & 20 & 397 \\
\hline C & - & - & 1 & 1 & 16 & 16 & 53 & 53 & 30 & 30 & 412 \\
\hline D & - & - & 1 & 1 & 21 & 21 & 58 & 58 & 20 & 20 & 397 \\
\hline \multicolumn{10}{|l|}{ Average }
\end{tabular}

Source: Primary data processed, 2016 Based on the responses of respondents on Organizational Leadership, the largest is 412 and the smallest is 395 .

\section{Personnel Management Variables}

The answers of the respondents can be presented in the table

Personnel Management Variable

\begin{tabular}{|c|c|c|c|c|c|c|c|c|c|c|c|}
\hline \multirow{3}{*}{ Question } & & \multirow{3}{*}{ Score } \\
\hline & \multicolumn{2}{|c|}{$0-20$} & \multicolumn{2}{|c|}{$21-40$} & \multicolumn{2}{|c|}{$41-60$} & \multicolumn{2}{|c|}{$61-80$} & \multicolumn{2}{|c|}{$81-100$} & \\
\hline & $\mathrm{F}$ & $\%$ & $\mathrm{~F}$ & $\%$ & $\mathrm{~F}$ & $\%$ & $F$ & $\%$ & $F$ & $\%$ & \\
\hline A & - & - & - & - & 21 & 21 & 43 & 43 & 36 & 36 & 415 \\
\hline B & - & - & 3 & 3 & 16 & 16 & 47 & 47 & 34 & 34 & 412 \\
\hline $\mathrm{C}$ & - & - & 5 & 5 & 20 & 20 & 36 & 36 & 39 & 39 & 409 \\
\hline $\mathrm{D}$ & - & - & - & - & 19 & 19 & 56 & 56 & 25 & 25 & 406 \\
\hline Average & & & & & & & & & & & 410.5 \\
\hline
\end{tabular}

Source: Primary data processed, 2016

Based on the responses of respondents regarding Personnel Management, the largest is 412 and the smallest 406 .

\section{Organizational Adhesive Variables}

The answers of the respondents can be presented on

Organizational Adhesive Variables 


\begin{tabular}{|c|c|c|c|c|c|c|c|c|c|c|c|}
\hline & \multicolumn{2}{|c|}{$0-20$} & \multicolumn{2}{|c|}{$21-40$} & \multicolumn{2}{|c|}{$41-60$} & \multicolumn{2}{|c|}{$61-80$} & \multicolumn{2}{|c|}{$81-100$} & \\
\hline & $F$ & $\%$ & $F$ & $\%$ & $\mathrm{~F}$ & $\%$ & $\mathrm{~F}$ & $\%$ & $\mathrm{~F}$ & $\%$ & \\
\hline A & - & - & 3 & 3 & 16 & 16 & 47 & 47 & 34 & 34 & 412 \\
\hline B & - & - & 1 & 1 & 21 & 21 & 58 & 58 & 20 & 20 & 397 \\
\hline C & - & - & - & - & 33 & 33 & 39 & 39 & 28 & 28 & 395 \\
\hline$D$ & - & - & - & - & 21 & 21 & 43 & 43 & 36 & 36 & 415 \\
\hline & & & & & & & & & & & 404.75 \\
\hline
\end{tabular}

Source: Primary data processed, 2016

Based on the responses of respondents regarding Personnel Management, the largest is 415 and the smallest 395.

Variable strategy that Emphasized

\begin{tabular}{|c|c|c|c|c|c|c|c|c|c|c|c|}
\hline \multirow{3}{*}{ Question } & \multirow{2}{*}{\multicolumn{2}{|c|}{$0-20$}} & \multirow{2}{*}{\multicolumn{2}{|c|}{$21-40$}} & \multirow{2}{*}{\multicolumn{2}{|c|}{$41-60$}} & \multirow{2}{*}{\multicolumn{2}{|c|}{$61-80$}} & \multirow{2}{*}{\multicolumn{2}{|c|}{$81-100$}} & \multirow{3}{*}{ Score } \\
\hline & & & & & & & & & & & \\
\hline & $\mathrm{F}$ & $\%$ & $\mathrm{~F}$ & $\%$ & $\mathrm{~F}$ & $\%$ & $\mathrm{~F}$ & $\%$ & $F$ & $\%$ & \\
\hline$A$ & - & - & 3 & 3 & 16 & 16 & 47 & 47 & 34 & 34 & 412 \\
\hline B & - & - & 1 & 1 & 21 & 21 & 57 & 57 & 21 & 21 & 398 \\
\hline C & - & - & - & - & 19 & 19 & 56 & 56 & 25 & 25 & 406 \\
\hline D & - & - & 1 & 1 & 21 & 21 & 58 & 58 & 20 & 20 & 397 \\
\hline verage & & & & & & & & & & & 403.25 \\
\hline
\end{tabular}

Source: Primary data processed, 2016 Based on the responses of respondents regarding Personnel Management, the largest is 412 and the smallest 397.

\section{Variable strategy that Emphasized}

The answers of the respondents can be presented in the table

\section{Variable Criteria of Success}

Variable Criteria of Success

Question

$0-20$

21-40

41-60

61-80

$81-100$

Score 


\begin{tabular}{|l|l|l|l|l|l|l|l|l|l|l|l|}
\hline & F & $\%$ & $F$ & $\%$ & $F$ & $\%$ & $F$ & $\%$ & $F$ & $\%$ & \\
\hline A & - & - & 1 & 1 & 21 & 21 & 57 & 57 & 21 & 21 & 398 \\
\hline B & - & - & - & - & 19 & 19 & 56 & 56 & 25 & 25 & 406 \\
\hline C & - & - & 3 & 3 & 27 & 27 & 41 & 41 & 29 & 29 & 396 \\
\hline D & - & - & - & - & 31 & 31 & 52 & 52 & 17 & 17 & 386 \\
\hline \multicolumn{19}{|l|}{ Average } & \multicolumn{10}{|l|}{} \\
\hline
\end{tabular}

Source: Primary data processed, 2016

Based on the responses of respondents regarding Personnel Management, the largest is 406 and the smallest is 386 .

\section{Discussion}

Discussion of research on Organizational Culture affecting growth and success of Small and Medium Enterprises (SMEs) in South Sulawesi Province that discusses dominant characters, organizational leadership, personnel management, organizational adhesives, emphasized strategies, and success criteria on the growth and success of SMEs. In analyzing the organizational culture that will be studied to be able to know how the growth and success of Small and Medium Enterprises in terms of organizational culture. More clearly can be seen the discussion based on descriptive descriptions that have been analyzed quantitatively in proving and finding answers to a problem posed in accordance with organizational culture.

The Dominant Character Affecting the Growth and Success of Small and Medium Enterprises (SMEs)

SMEs strive to increase their revenues by priority quality so that organizations or businesses make personal places like big families and people share with each other. This dominant character is also a very dynamic place for every member of an organization willing and willing to take risks. However, prioritizing and results-oriented is the ultimate goal of completing the work of every member of an organization that is both competitive and results-oriented. In the dominant character, the organization is a highly controlled and structured place with formal procedures to control what people do.

Organizational Leadership Affecting the Growth and Success of Small and Medium Enterprises

The results of general testing of organizational culture that influence the growth and success of SMEs in terms of leadership in organizations and businesses that are as mentors, facilitators who always provide entrepreneurship guidance, innovative and daring to take risks and are aggressive and focused on achieving results. That's what will continue to be the liaison in terms of organizational culture in influencing the growth and success of SMEs.

Personnel Management Affecting the Growth and Success of Small and Medium Enterprises (SMEs)

Based on the results of the data show that personnel management is characterized by teamwork, agreement, and participative who dare to take risks, innovative and give freedom and uniqueness to each individual. Management in this organization is characterized by competitive demands of high demand in achieving results. And the main one in personnel management is characterized by a 
sense of security in the employee, the uniformity, predictability, and stability of the relationship.

Organizational Adhesives Affecting the Growth and Success of Small and Medium Enterprises (SMEs)

From the results of processed organizational culture data consisting of organizational adhesive is loyalty and mutual trust, commitment, which is very important in organization and business. The adhesive of this organization is a commitment to innovation and development that always focuses on the most up-to-date things and achievement and achievement of goals, aggressiveness, and victory is the main thing that can unite within the organization is a formal policy.

Emphasized Strategies Affecting the Growth and Success of Small and Medium Enterprises (SMEs)

From the results of this business organization data emphasizes the development of human resources, high trust, openness, participation, and always involves each employee. This strategy emphasizes the discovery of new resources and creates new challenges to dance new opportunities. The culture of this organization emphasizes competition and achievement and winning the market is a priority.

Success Criteria Affecting the Growth and Success of Small and Medium Enterprises (SMEs)

In the results of the data show that the success criteria within the organizational culture are successful on the basis of human resource development, teamwork, Commitment of employees and care for members of the organization. The priority of success based on winning the competition is the key to success based on efficiency, reliable products, and services. Routine and production schedules with low production costs are critical.

\section{CLOSING \\ Conclusion}

Based on the results of research and discussion above it is concluded:

1. To identify the cultural profile of an organization developed an instrument called Organizational Culture Assessment Instrument (OCAI). This framework consists of two dimensions that distinguish focus on flexibility, discretion, and dynamism but more importantly is focused on stability, command, and control.

2. To identify an organization's cultural profile developed in terms of focusing on Internal, Integration, and Unity orientation. And most importantly on external orientation, differentiation, and competition.

3. To identify the cultural profile of an organization developed with the characteristics of closeness, participation, cooperation, and worker commitment achieved through participation, closeness, and personal satisfaction is more important than financial objectives. While the characteristics of the market (market) focused on competition and achievement of goals.

\section{Suggestion}

1. Although Small and Medium Enterprises (SMEs) are experiencing growth with businesses that produce a certain superior product then the efforts to identify investment opportunities to produce superior 
products that have the power to develop a need to be done so that it can have a high enough added value in absorbing energy More work.

2. Although small business contributing significantly to the Indonesian economy means that SMEs should be more innovative, initiative, and have the capability for new technology so that it can compete and can develop for the national, as well as global economy.

3. SMEs as a pillar of a populist economy that can be a major driver of the regional economy should be more specialized in realizing the program "Gerbang Mas Taskin dan Agribisnis Komoditas Unggulan" in South Sulawesi, then it must prove the existence of strategy and action plan in building micro and small business, devoted to training and mentoring program.

\section{REFERENCES}

Acs, Z. and Audretsch, D., 1990, The Economics of Small Firms: $A$ European Challenge, Kluwer Academic Publishers, Norwall, MA.

Andersson, S. and Tell, J. (2009), The relationship between the manager and growth in small firms, Sweden Journal of Small Business and Enterprise Development Vol. 16, No. 4

Barth, $\mathrm{H}$ (2004), Barriers to growth and development in small firms, Doctoral Thesis, Lulea University of Technology, Lulea

Baum. J Robert, Edwin. A. Locke dan Ken G Smith, 2001, "A Multidimensional of Venture Growth. Academic Management
Journal, Vol. 44 No. 2, 292-303.

Cameron, K and Quinn, R (1999), Diagnosing and Changing Organizational Culture, Prentice Hall

Cameron, Kim (2004), A Process for Changing Organizational Culture, University of Michigan Business School.

Chandler, G. N, \& Hanks, S. H. 1994. "Founder competence, the environment and venture performance". Entrepreneurship Theory and Practice, (Spring), 77-89.

Demirbag, M., Tatoglu, E., Tekinkus, M. and Zaim, S., 2006, "An analysis of the relationship between TQM implementation and organizational performance: evidence from Turkish SMEs", Journal of Manufacturing Technology Management, Vol. 17 No. 6, pp. 829-47.

Dennison, D. R (1996). What is the difference between organizational culture and organizational climate? A natives point of view on a decade of paradigm wars. Academy of Management Review 2(3), pp. $619-654$

Deshpande, R. Parley, J.U. \& Webster, F.E (1993), Corporate culture, customer orientation and innovativeness in Japanese Firms: Quadran Analysis, Journal of Marketing, 57(January), pp. $23-37$.

Dinas Koperasi dan UKM Sulawesi Selatan, 2013. " Data Usaha Mikro, Kecil dan Menengah (UMKM) ".

Endosomwan, The Johnson A. 2009. "Strategic Leadership and Innovation in High Technology Firms". White Paper Series. The university of Miami. 
Greenberg, J. \& Baron, R.A. 2008. Behavior in Organizations. Ninth Edition, Prentice Hall, New Jersey.

Gunday G, Ulusoya G, Kilica K, and Alpkanb L, 2009, "Effects of Innovation Types on Firm Performance, Journal, Faculty of Engineering and Natural Sciences, International Journal of Production EconomicsVolume 133, Issue 2, October 2011, Pages 662-676.

Hafeez. M. H, Shariff. M. N, Lazim. M. 2012, "Relationship between Entrepreneurial Orientation, Firm Resources, SME Branding and Firm' Missing Link?, American Journal of Industrial and Business Management, Vol 2 No. 4 pp153-159.

Halikias, J, and Panayotopoulou, L (2003), Chief executive Personality and export involvement, Management Decision Vol. 41 No. 4, pp. 340350

Hilmi. M.F, Ramayah.T, 2008, Market Innovativeness of Malaysian SMEs: Preliminary Result from a First Wave Data Collection, Asian Social Science, Vol.4, No. 12. (Online)Des 2008: pp 42-49

Hurley, F.R, Hult, G.T.M, and Knight, G.A. 2003. "Innovativeness: Its Antecedents and Impact on Business

Performance". Journallndustrial Marketing Management. Vol 33. pp: 429-438.

Kotey, Bernice; Meredith, GG. 1997. "Relationship Among Owner/Manager Personal Value, Business Strategies, and Enterprise", Journal of SmallBusiness Management, P.37-61

Lee Shang. T, Sukoco, and Munir. B,
2007. 'The Effects of Entrepreneurial Orientation and Knowledge Management Capability on Organizational Effectiveness in Taiwan: The Moderating Role of Social Capital". InternationalJournal of Management, Vol 24 Issue 3, p549.

Levin, I (2000), Five windows into organization culture: An assessment framework and approach. Organization Development Journal, 18(1), pp. $83-94$.

Lin C. \& Tseng S., 2005. "Bridging the implementation gaps in the knowledge management system for enhancing corporate performance", Expert Systems with Applications, Journal Elsevier, Vol 29 Issue 1 pp: 163173

Martins, E.C and Terblanche, F. (2003), Building organizational culture that stimulates creativity and innovation, European Jurnal of Innovation Management Vol. 6, No. 1 , pp. $64-74$

Murphy, Kevin M. \& Shleifer, Andrei \& Vishny, Robert W. 1990. "The Allocation of Talent: Implications for Growth," NBER Working Papers 3530, National Bureau of Economic Research, Inc.

P Davidsson, J Wiklund (2001), Levels of analysis in entrepreneurship research: Current research practice and suggestions for the future, Entrepreneurship Theory and Practice, p. 245

Pelham, M. Alfred, David T. Wilson. 1996, "A Longitudinal Study of The Impact of Market Structure, Firm Structure, Strategy, and Market Orientation Culture on Dimensions of Small Firms Performance", Journal of 
Academy of Marketing Science. 24, 1, pp. 27-43

Prakosa, Bagas. 2005. "Pengaruh Orientate Pasar, inovasi dan orientasi pembelajaran terhadap kinerja perusahaan untuk mencapai keunggulan bersaing (Study empiris pada industri manufaktur di Semarang)". Jurnal Study Manajemen \& Organisasi,2(1),35-37.

Primiana, I., 2011.

MengembangkanAlternatif Pembiayaan DanPemasaran UKM. Diakses padatanggal 2 April 2016 dihttp://www.bisnisjabar.com.

Ritchie, J. (1993). Strategies for human resource management: challenges in smaller and entrepreneurial organizations, in Harrison, R. (Ed.), Human Resource Management, Addison-Wesley, Wokingham, pp. 111-35.

Sanchez, Antonio Aragon; Marin, Gregorio - Sanchez, 2005, "Strategic Orientation,
Management Characteristics, And Performance: A Study Of Spanish SME's", Journal Of Small Business Management, Vol. 43. N 3 Pp 287-306

Swamidass, P. M \& Newell, W. T. 1987. "Manufacturing Strategy, Environmental Uncertainty, and Performance": A Path Analytic Model", Management Science, Vol. 33, No. 4, pp. 505-525.

Tambunan, T. 2012. "Pasar Bebas ASEAN, Tantangan, Peluang dan Ancaman bagi UMKM Indonesia", Infokop.

Tika, Moh. Pandu. 2005. Kinerja Perusahaan. Edisi Pertama, Penerbit Erlangga : Jakarta.

Zhou, Kevin, Zheng, Chi Kin Yim, and David K. 2005. "The Effect of Strategic Orientations on Technology and Marker-Based Breakthrough Innovations". Journal of Marketing Vol 69 p4260. 